\title{
Effects of the inhibition of weed communities by winter-flooding
}

\author{
Korehisa Kaneko ${ }^{1^{*}}$, Toshihiko Nakamura ${ }^{2}$ \\ ${ }^{1}$ Hokuso Creature Association, Tabata, Tokyo, Japan; *Corresponding Author: k_kaneko@hotmail.com \\ ${ }^{2}$ Natural History Museum and Institute, Chiba, Japan.
}

Received 9 September 2011; revised 14 October 2011; accepted 26 October 2011.

\begin{abstract}
Winter-flooded paddy field is an agricultural method which putting a water among the winter, it is paid attention as an environmental friendly agriculture. Especially, it is said, winter-flooding is control paddy weeds and there is the farming potential that the annual rice yield is high. However, there is no detailed research about the effects of weed communities by winter-flooding, as the purpose of this study, we investigated the effects of the inhibition of weed communities (life cycle, harmful weed) by winter-flooding at a shore of Inba Lake, Chiba Prefecture, Japan, and compared them to paddy weeds in a dry paddy field. Methods examined the plant height (cm) and the cover degree class of all appearance species in each quadrant frame $\left(1 \mathrm{~m}^{2}\right)$. Quadrant in the two type paddies were 10 frames (D1-D10) at the control, and were 10 frames (W1-W10) at the treatment (Figure 1). In a winter-flooded paddy field, species number and plant volume of winter-annual plants decreased in the third winter after winter-flooding, In particular, the plant volume of Alopecurus aequalis, Cardamine flexuosa decreased significantly. We considered that the cause of this decrease was due to the depth of flooding (more than $10 \mathrm{~cm}$ ). Eleocharis kuroguwai and Sagittaria trifolia, which are perennial plants, Echinochloa oryzoides, which is an annual plant, increased in a winter-flooded paddy field in the third summer after winter-flooding. We considered that these species grew thicker at places where the seeds germinated, and grew easily, because the conservation situation of the seeds fitted well under the winter-flooding conditions. They started to grow immediately after the drainage of water. The period of drainage coincided with increasing light intensity and temperature. In addition,
\end{abstract}

the annual rice yield of the third year after winter-flooding was higher than that of the habitual practice rice field.

Keywords: Winter-Flooded Paddy Field; Life Type; Harmful Weeds; Biodiversity; Environmental Agriculture

\section{INTRODUCTION}

In Basic Law on Food, Agriculture and Rural Areas which enacted in 1999, it is requested the sustainable demonstration of multi-functionality, not only the stable supply of food, but also the conservation of country and water-source, the formation of natural environment and excellently landscape etc through the productive activity. Afterwards, original biodiversity strategy is enacted in [1] and [2], environmental friendly agriculture has been contained as one of the biodiversity conservation.

In revision of Ramsar convention in 2005, rice paddy fields were registered, in particular, winter-flooded rice farming which is conducted in Kabukuri-numa and the surrounding rice paddies is attracting attention as an environment to be worthy not only the safety and healthy rice but also the respect of biodiversity as used land of many waterfowls.

In winter-flooding, the paddy of non-irrigation period is the flooding state, as the effects, the water-source conservation in winter and water quality purification [3], the offer of biotope to wetland including waterfowl etc. [4], the effects of agricultural management of accompanying additional value as the effects of the weed suppression and environmental preservation rice [5-7]. [8] reported that the effects of the weed suppression found in the second winter after winter-flooding. However, there is no research example of the detailed examination as the effects that the winter-flooding exerts on life cycle (annual plant, winter-annual plant and perennial plant) of paddy weeds and harmful weeds. These are the problems which should be examined to promote the winter-flood- 
ing in the future.

This study aimed to clarify the effects of the inhibition of weed communities by winter-flooding, comparing to plant communities between before winter-flooding (the first year) and the third year after winter-flooding (the finality year), based on a vegetation survey of the winter-flooding examination.

\section{MATERIALS AND METHODS}

\subsection{Study Site}

Study site is suited at a large-scale rice field of the Hagiyama Shinden section in a shore of Inba lake in Sakura City, Chiba Prefecture, Japan.

Paddy field in this area has produced Koshihikari. Field experiments were set as the treatment where the winter-flooding was conducted and the control where the habitual practice rice farm was continued. In the first year of winter-flooding, water put in January 2006, scratched and planted rice was conducted in May, the herbicide was scattered in June, the drainage of water was conducted in the middle of August, rice was harvested in the middle of September. The rice bran was scattered in October, water was flooded in the beginning of November. In the second year, the scratching, the planting rice, the drainage of water, the harvesting rice, the flooding were almost conducted at same periods in the first year, the herbicide was not scattered. However, the herbicide scattered in the third June.

The mean water depth was about $10 \mathrm{~cm}$ at the first and the second year, and was about $12 \mathrm{~cm}$ in the third year. The winter-flooding was supplied at constant intervals using a pump. The scratching, the planting rice, the drainage of water, the herbicide scatter conducted at the same time on the control of dry paddy and the treatment before winter-flooding.

\subsection{Vegetation Survey}

The vegetation survey was conducted in August, October, and December which are both the first year and the third year, and methods examined the plant height (cm) and the cover degree class of all appearance species in each quadrant frame $\left(1 \mathrm{~m}^{2}\right)$.

Quadrant in the two type paddies were 10 frames (D1-D10) at the control, and were 10 frames (W1-W10) at the treatment (Figure 1).

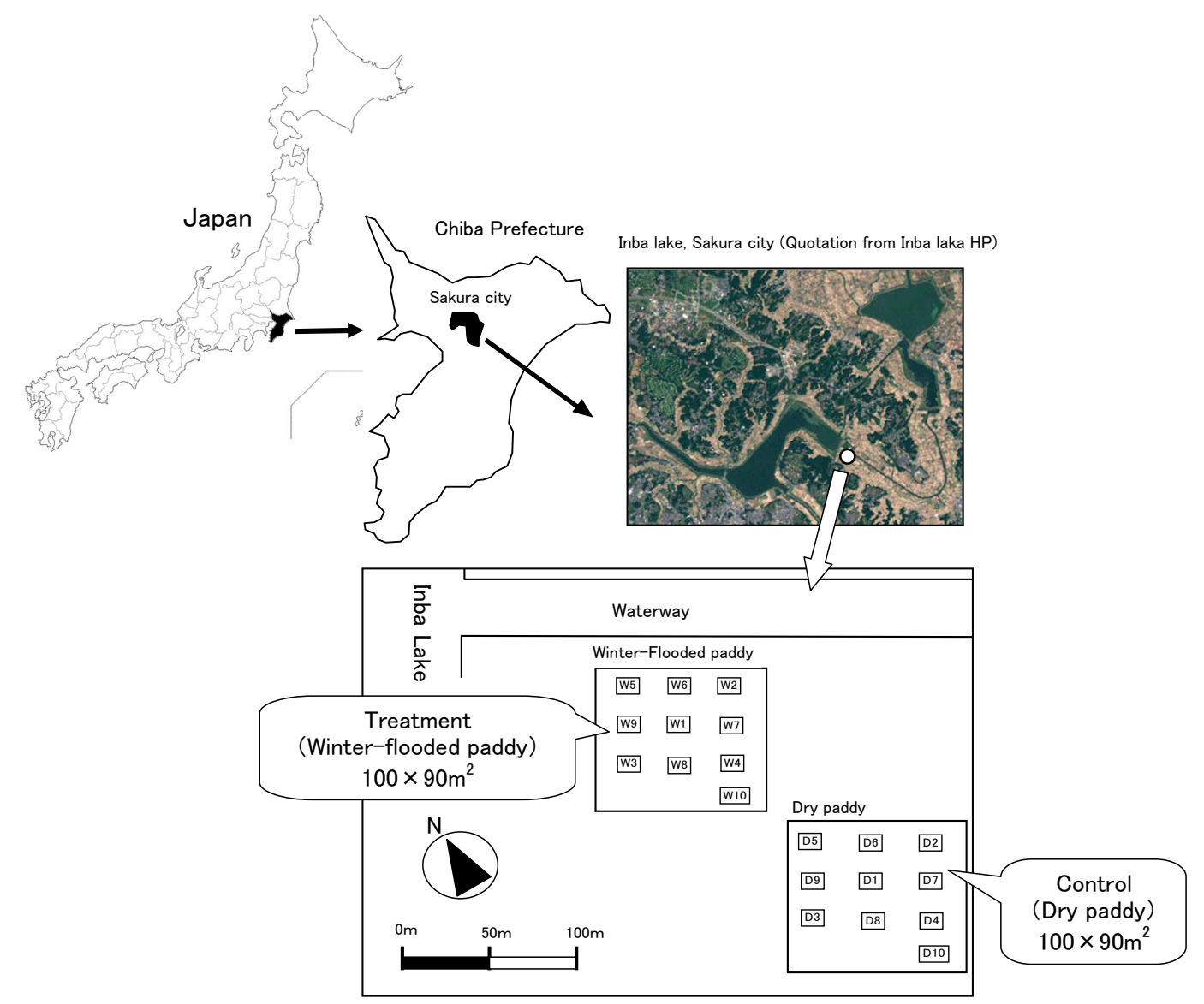

Figure 1. Investigation position. 


\subsection{Analysis}

The plant volume of each species (=the average rate $(\%) \times$ the plant height $(\mathrm{cm})$ ) calculated as an index of the plant biomass. The average rate converted each cover degree class $(+:<1 \%, 1: 1 \%-5 \%, 2: 5 \%-25 \%, 3: 25 \%$ 50\%, 4: $50 \%-75 \%, 5: 75 \%-100 \%)$ into $0.1 \%, 2.5 \%$, $15 \%, 37.5 \%, 62.5 \%$, and $87.5 \%$, based on [9].

In addition, in order to examine the changes of the composition and the structure of plant communities in the two type paddies, the cover degree $(+, 1,2,3,4,5)$ of appearance species in the quadrant frame of each section (+ class converted into 0.1 and the following class was not converted) were analyzed by cluster analysis, using the group average method (PC-ORD: Windows version 4.01).

As for the life circle's definition, the annual plant is a plant that germinates the seed, flowers, brings forth within one year, leaves the seed, and withers. The winter-annual plant is a plant that the seed germinates in autumn, passes the winter at rosette, it will flower and bring forth next year. The perennial plant is a plant that it is growing as an individual for two or more years.

\section{RESULTS}

\subsection{Species Number in before and after Winter-Flooding}

Compared to species number between the treatment and the control in before winter-flooding (2005) and the third year after winter-flooding (2008), although all founded species did not have a significant difference with before winter-flooding, and were significant difference $(5 \%)$ in the third December, species number was little at the treatment. This result has seen the same tendency with winter-annual plant (Figure 2).

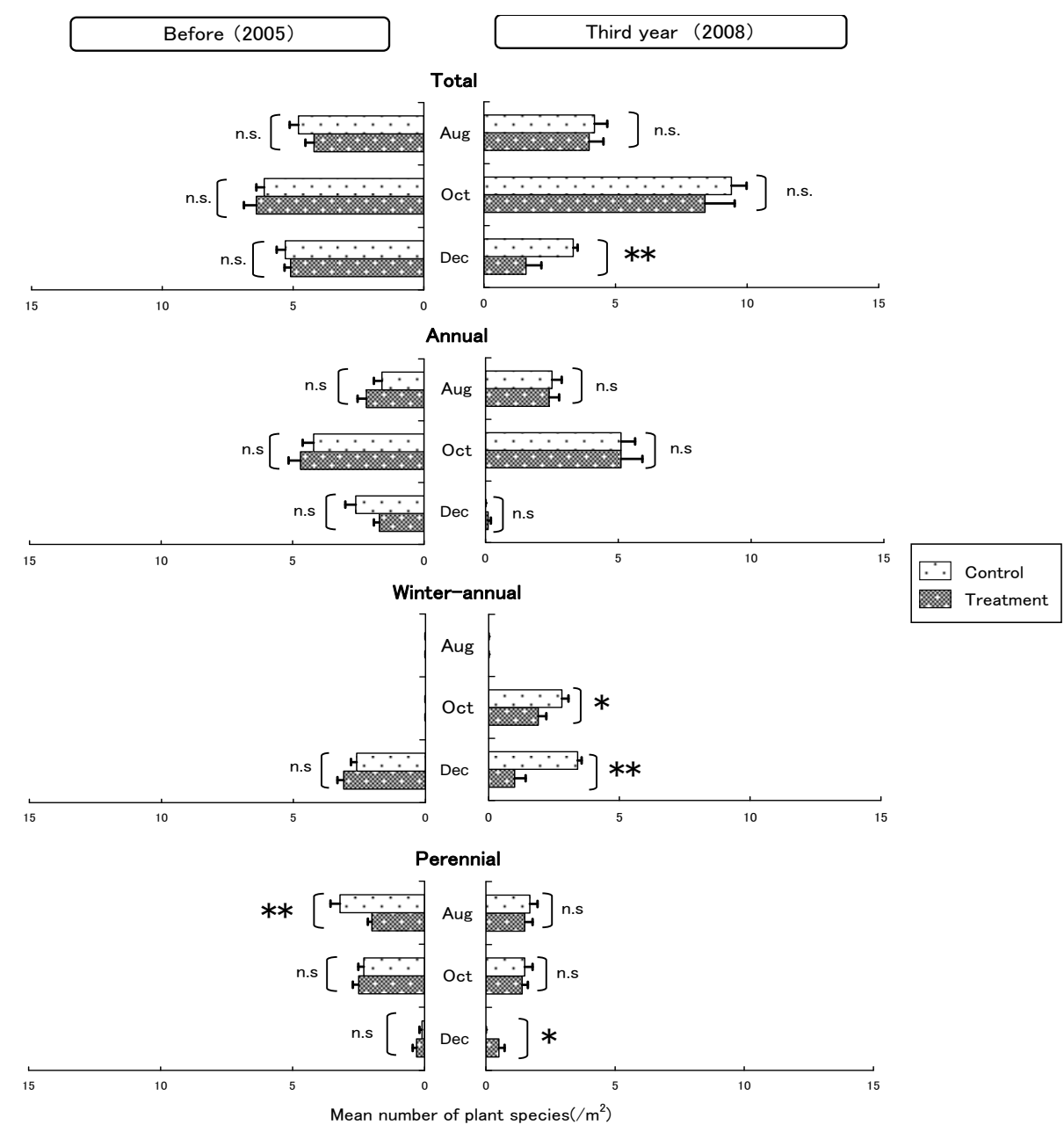

Figure 2. Mean number of plant species of total and each life type in treatment (winter-flooded paddy) and control (dry paddy). **: $1 \%$ significant, *: 5\% significant, n.s.: non-significant. Horizontal stick shows mean value of standard error margin. Significant used t-authorization of student. $\mathrm{N}=10$ shows sample number of each quadrant. 


\subsection{Plant Volume in before and after Winter-Flooding}

Compared to plant volume between the treatment and the control in before winter-flooding (2005) and the third year after winter-flooding (2008), plant volume were little at the treatment in the third December, a significant difference was at $1 \%$. This was the same tendency with winter-annual plants (Figure 3).
Before (2005)
Third year (2008)

\section{Total}
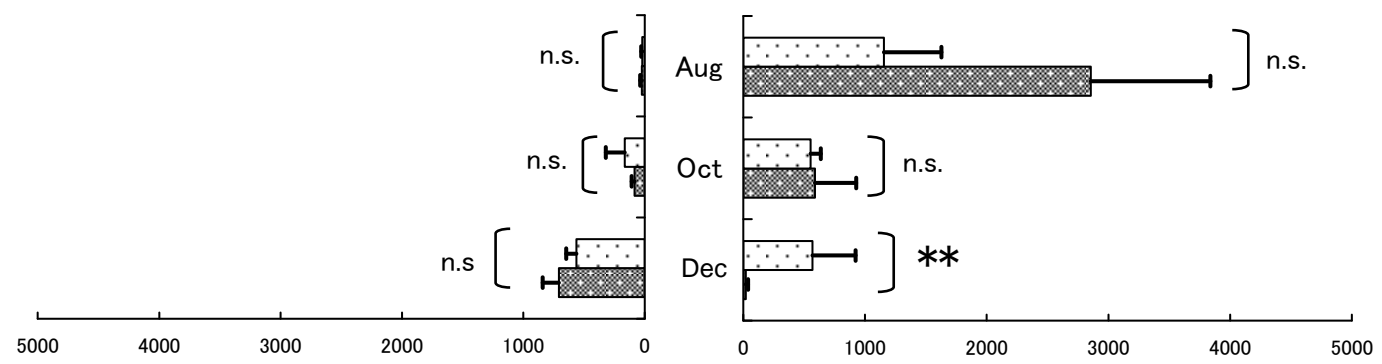

Annual
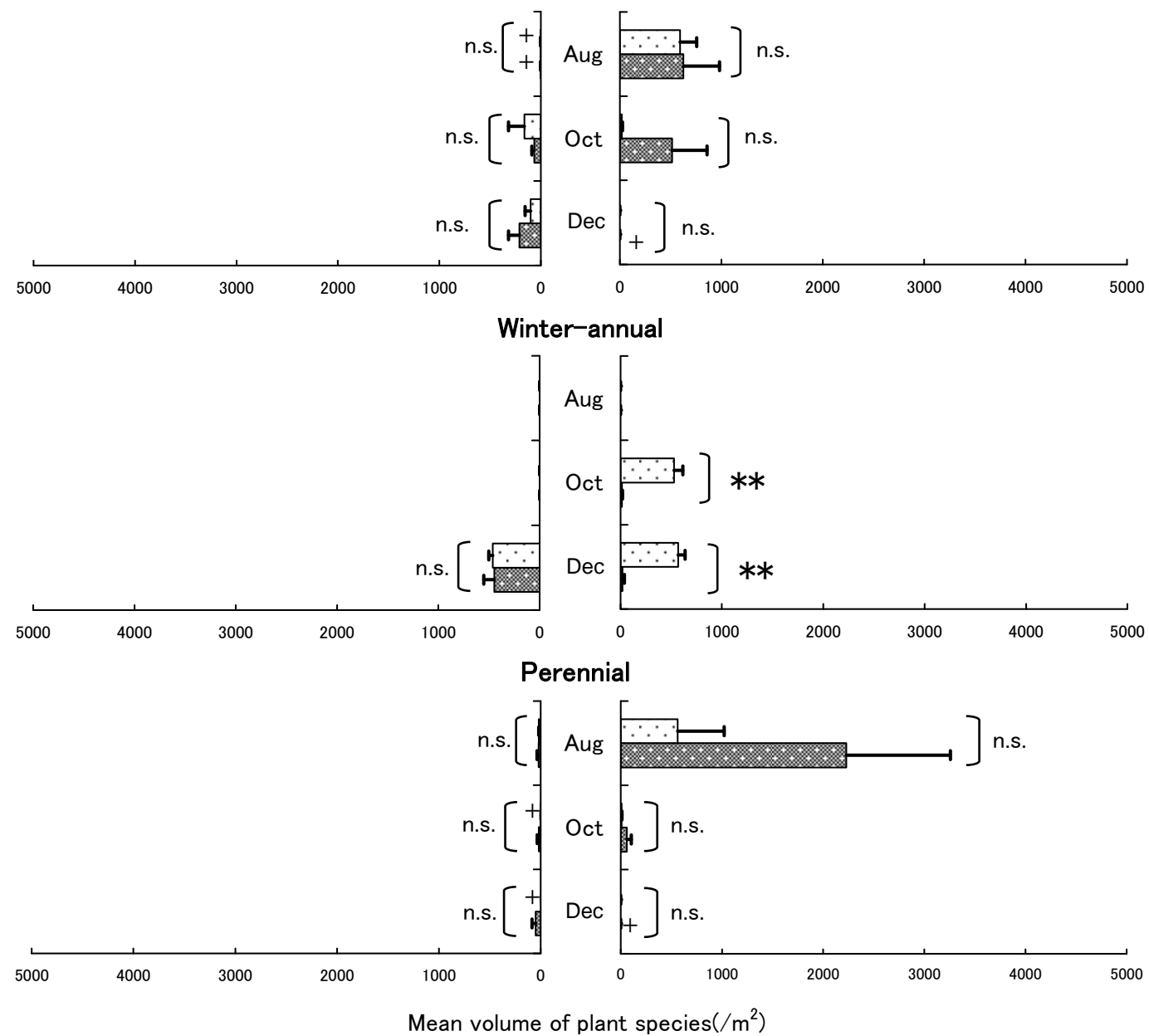

Figure 3. Mean volume $\left(/ \mathrm{m}^{2}\right)$ of plant species of total and each life type in treatment (winter-flooded paddy) and control (dry paddy). **: $1 \%$ significant, *: $5 \%$ significant, n.s.: non-significant. Horizontal stick shows mean value of standard error margin. Significant used t-authorization of student. $\mathrm{N}=10$ shows sample number of each quadrant. 
As the main paddy weeds which influenced the changes of the plant volume in the above-mentioned, an annual plant was Echinochloa oryzoides, the winter-annual plants were Alopecurus aequalis, Cardamine flexuosa, the perennial plants were Eleocharis kuroguwai, Sagittaria trifolia. Compared to mean plant volume between the treatment and the control, Echinochloa oryzoides was hardly founded in before winter-flooding, however, it was high at the treatment in the third summer. Alopecurus aequalis, Cardamine flexuosa were high in the winter of before winter-flooding, however, were low at the treatment of the third year. Eleocharis kuroguwai, Sagittaria trifolia were hardly founded in before winter-flooding, however, they were extremely high at the treatment in the third summer (Figures 4 and 5).

\subsection{Species Composition in before and after Winter-Flooding}

Cluster analysis was conducted in order to examine the changes of the composition and the structure in weed communities in before winter-flooding and the third year (Figure 6). It analyzed species composition according to August, October, and December. As a result, the separa- tion by clusters between the treatment and the control were not confirmed in before winter-flooding, however, in the third year, the treatment was separated with the control except for W10 of October, W3 of December, and was non-vegetation at 5 points (W1, W2, W7, W9, W10).

\section{DISCUSSION}

As for the affects on weed communities by winterflooding, species number and plant volume of winterannual plants decreased in the treatment of the third December, especially, Alopecurus aequalis, Cardamine flexuosa greatly decreased. Although Alopecurus aequalis germinate under conditions in which the temperature is high, and the oxygen is satisfactory after the drainage of water, germination is delayed in ill-drained paddy fields and those that are non-tilled with high groundwater level, and will be carried over until spring of the following year. The longevity of the seed is short from half a year to a year, and the semination ability is low. The number of seeds which dropped in the farmland provides for the amount of generation in the farmland of the next generation [10].

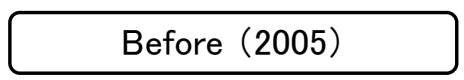

Third year (2008)

\section{Alopecurus aequalis (Winter-annual)}
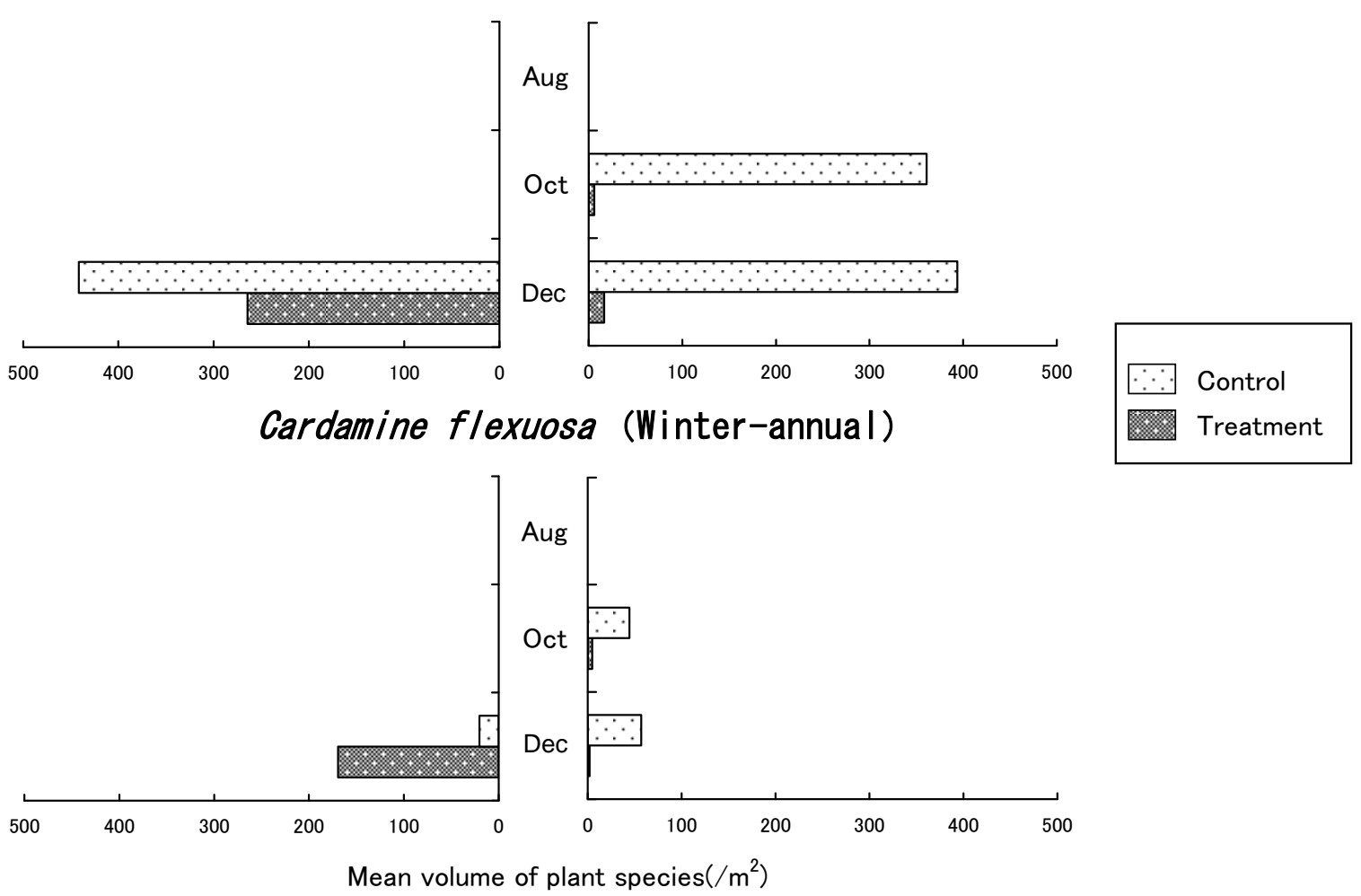

Figure 4. Mean volume $\left(/ \mathrm{m}^{2}\right)$ of plant species which decreased by winter-flooded. 

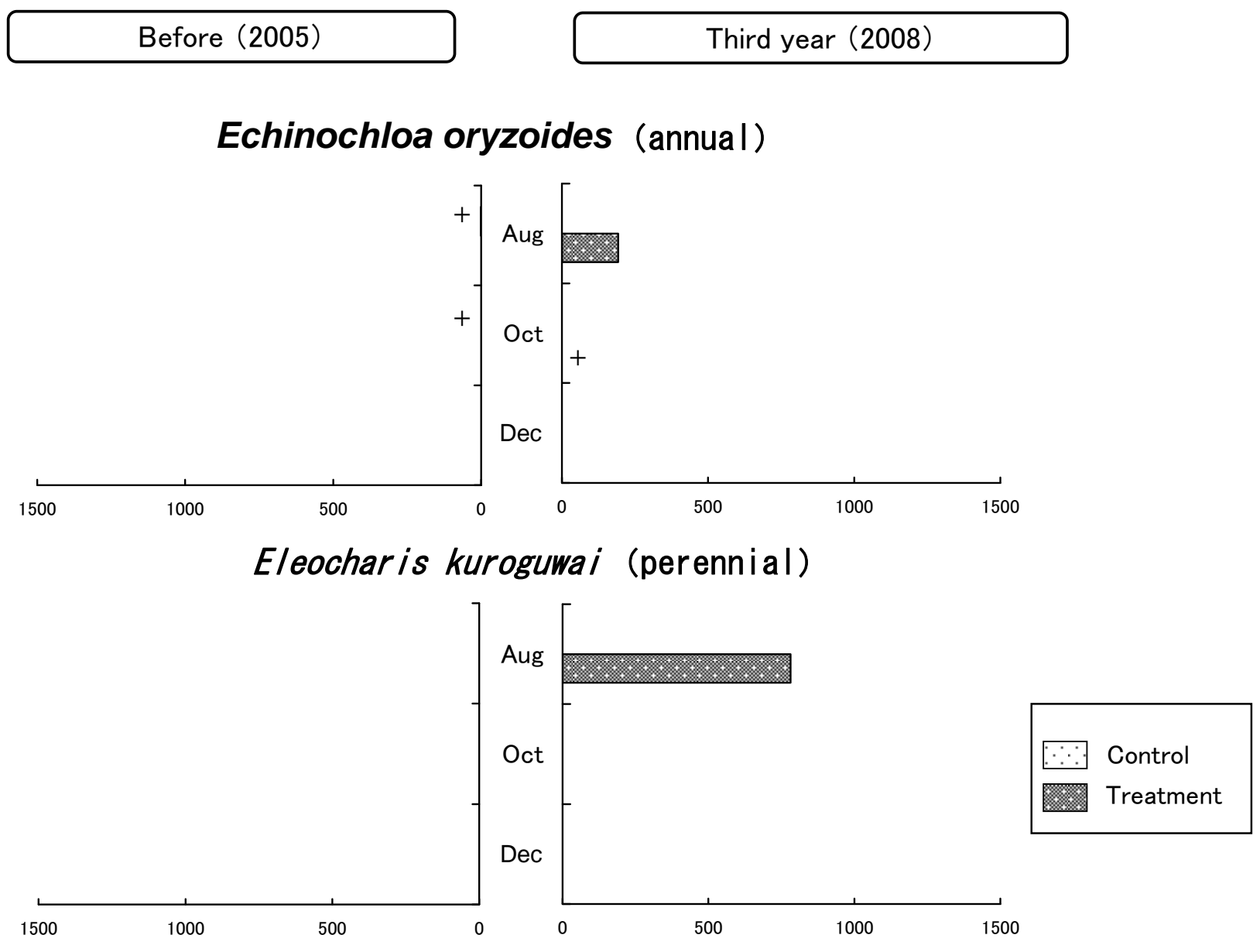

$1500 \quad 5000$

Sagittaria trifolia (perennial)

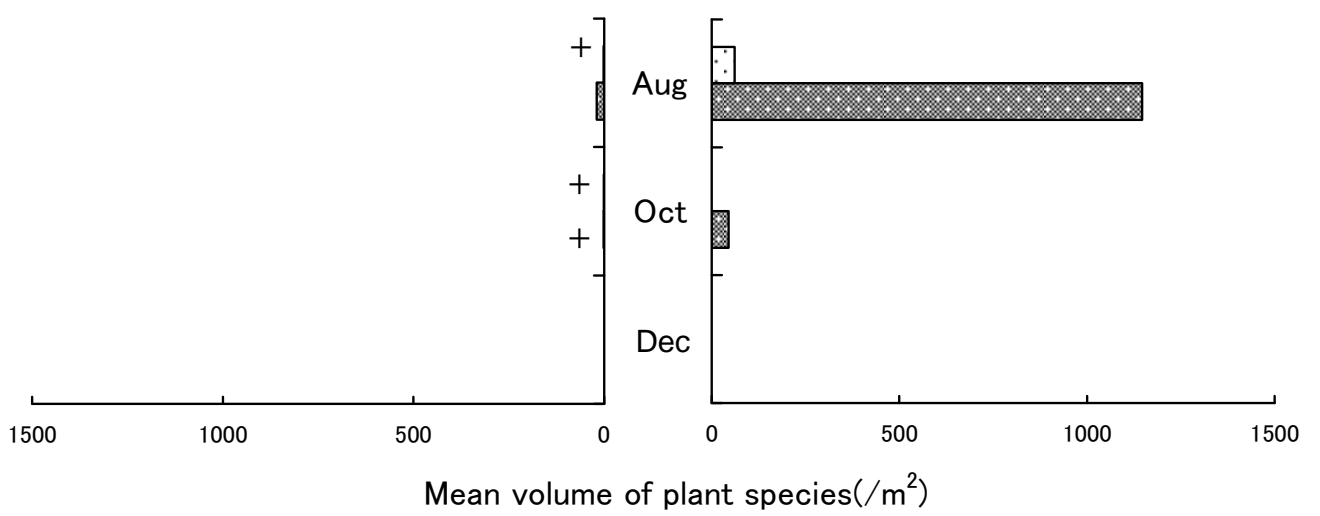

Figure 5. Mean volume $\left(/ \mathrm{m}^{2}\right)$ of plant species which increased by winter-flooded. + : means not showing on the drawing because of extremely the value low.

Moreover, [11] reported that Alopecurus aequalis withered in a paddy field where the flooding was maintained enough in winter, and was generated in a paddy field where the flooding was not maintained, and a final amount of generation tripled. [12] reported that the generation rates of Alopecurus aequalis and Cardamine flexuosa in a moist soil state were higher than those in a flooding water depth of $5 \mathrm{~cm}$.

We considered that the germination and growth of these species were inhibited by the flooding water depth of $12 \mathrm{~cm}$ in autumn that winter-annual plants germinate, and it greatly had an effect on the difference of species composition between the treatment and the control in winter. 

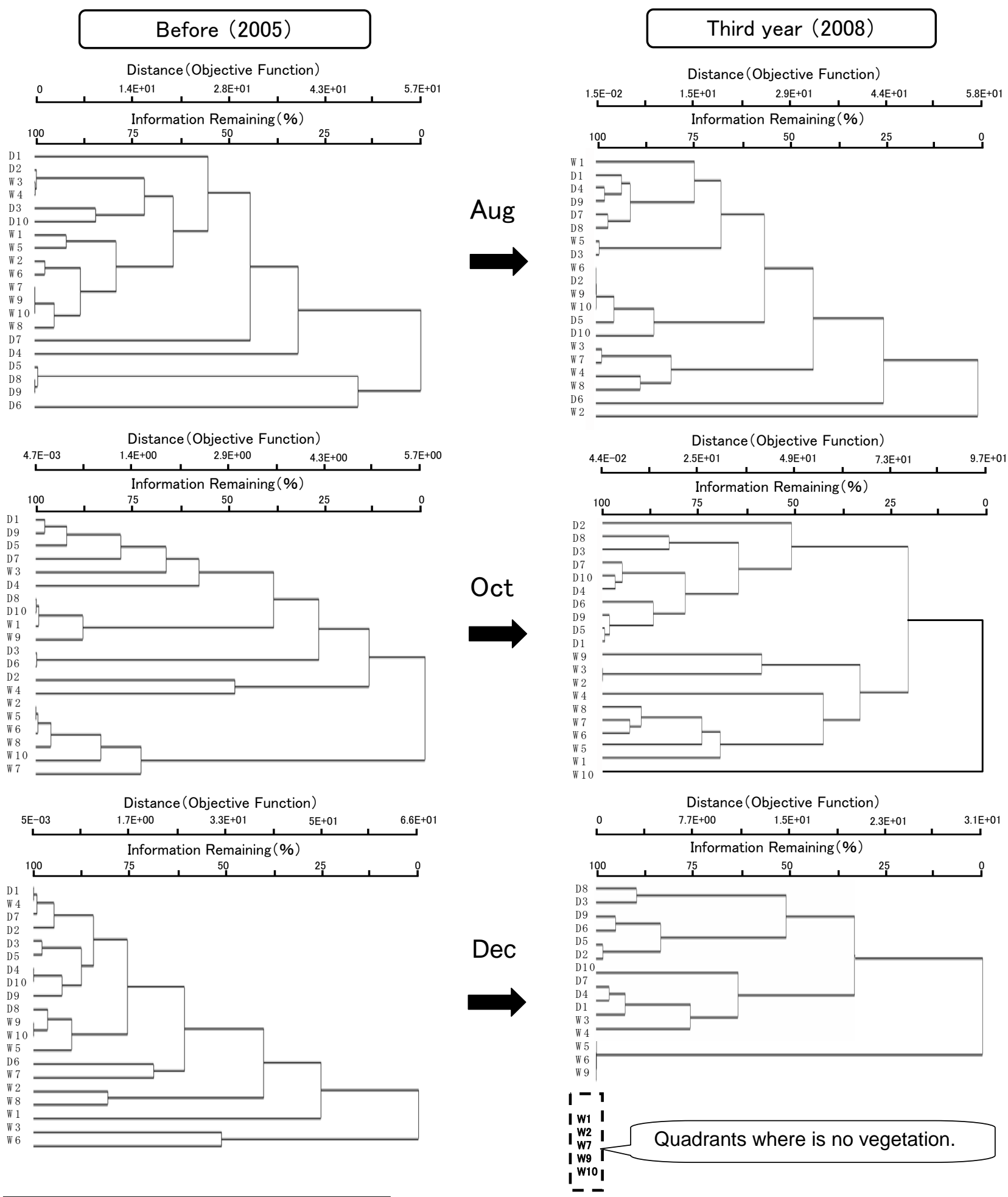

※Treatment $(\mathrm{W} 1 \sim \mathrm{W} 2)$, Control $(\mathrm{D} 1 \sim \mathrm{D} 10)$

Figure 6. Difference of vegetation of each quadrant in treatment (winter-flooded paddy) and control (dry paddy).

[8] reported that Monochoria vaginalis of the annual plants grew thicker at the treatment in the second summer. However, Monochoria vaginalis of the third year did not grow thicker in comparison to that of the second year, but instead, Echinochloa oryzoides of the annual plants and Eleocharis kuroguwai, Sagittaria trifolia 
of the perennial plants grew thicker in summer of the third year. Although a lot of seeds of Alopecurus aequalis die out in dry paddy fields during the cryogenic period from late autumn to the early spring, and the seed survival time of Alopecurus aequalis in the soil is short, in case of the paddy in the flooding state during year, the extinction of the seeds in the process of the dormancy awakening is hardly generated, the seed longevity are longer compared with the dry paddy [13]. Moreover, the population growth rate, the leaf area, and the net assimilation rate of Alopecurus aequalis are high under the conditions in which the quantity of solar radiation and the temperature are high [14]. The sprout rate of tuber of Eleocharis kuroguwai is high in flooded paddy fields of paddling and under the strong reduction soil of nontillage, however, they are low under the conditions of low temperature and drying treatment [15]. The germination rate of Eleocharis kuroguwai is high under flooding conditions, and is low under drying conditions [16].

The production rate of the seed was high under the conditions of strong light and eutrophication, and water depth was growing excellently by $3-15 \mathrm{~cm}$. In the case in which these conditions exceeded the limit, it became the life circle only vegetative propagation system, and the tuber died out considerably by tillage and germinated gradually after paddling [17]. We considered that the seeds of Echinochloa oryzoides, Sagittaria trifolia, Eleocharis kuroguwai were in an excellent conservation state by the winter-flooding, after the drainage of water, in case that it became the state under the conditions in which direct sunshine was strong and temperature was high, the seed germinated and grew. Especially, in the third year, Eleocharis kuroguwai and Sagittaria trifolia grew remarkably thicker than Monochoria vaginalis. As one of the agricultural factors related to the decrease of annual plants and the succession to the perennial plant communities such as Eleocharis kuroguwai and Sagittaria trifolia, a decrease of hand weeding by herbicide scatter was the cause [18]. Therefore, we considered that the use of the herbicide influenced the decrease of Monochoria vaginalis in the third year. As other causes, we considered that the tuber of Eleocharis kuroguwai and Sagittaria trifolia which germinated and grew in the second year had increased after the winter-flooding, and the vegetative propagation was actively done and grew thicker in the third year, because the treatment plowed a field lightly.

Although the volume of annual rice yield was high at the control before winter-flooding, in the third year, it was high at the treatment, therefore, we can be said that there is little influence due to a mat of weeds in summer. However, [19] reported that the production rate of rice decreased in winter-flooded paddy fields (the flooding began in the middle of December) in which paddy weeds grew thicker. This result is different from this research study results. We have considered the beginning period of winter-flooding and climate influences, and that they are problems to be solved in the future.

\section{ACKNOWLEDGEMENTS}

This research conducted as a part of Mitamesi winter-flooding project and Mitamesi action of "The Committee for Lake Inba-numa Watershed Management”. As for advancing the research, we are very indebted to Dr. Katumi Musiake chaiman, Chiba Prefecture River Environment Division, other parties concerned, and, Mr. Masuo Mikado who cooperated in this research to offer the rice field while making rice. Moreover, as for writing this paper, we got an offer of the document material and valuable advice from Dr. Takuya Mineta of National Institute for Rural Engineering, Dr. Hiroshi Jinguji who is Associate Professor of Miyagi University. We wish sincerely to express our gratitude to everybody.

\section{REFERENCES}

[1] Ministry of Agriculture, Forestry and Fisheries (2007) MAFF's biodiversity strategy. Ministry of Agriculture, Forestry and Fisheries, Tokyo, Japan.

[2] Chiba Prefecture (2008) Biodiversity Chiba Prefecture strategy. Chiba Prefecture, Chiba, Japan.

[3] Kurita, H., Mineta, T., Ishida, K., Ashida, T. and Yagi, H. (2006) Environmental potential of winter-flooding rice field for the wetlands restoration. Transactions of the Japanese Society of Irrigation, Drainage and Rural Engineering, 74, 713-717.

[4] Iwabuchi, N. (2003) Importance and application in winter-flooding rice field-Circulation type technology support ecosystem maintaining ecosystem. Rural Area and Environment, 19, 50-59.

[5] Iwasawa, N. (2003) It revives by non-tillage. Sosinsha, Tokyo, Japan.

[6] Yamamoto, H., Ohhata, K. and Yamamoto, K. (2003) The effects of water flooding and provision of the food for wintering ducks on rice fields-A preliminary study for establishing a stable wintering duck population at Katano-kamoike III. Strix, 21, 111-123.

[7] Mineta, T., Kurita, H. and Ishida, K. (2004) Potential of Winter-flooding rice field in regard to farming and the multifunctionality-Analysis of status by questionnaire and interview survey to operative farmers. Transactions of Rural Planning, 6, 61-66.

doi:10.2750/arp.23.23-suppl_61

[8] Kaneko, K. and Nakamura, T. (2009) Winter-flooding has an effect on paddy weeds. Japanese Journal of Landscape Ecology and Management, 14, 67-72.

[9] Braun, B.J. (1964) Pflanzensoziologi. Grundzuge der vegetationskunde. Springer-Verlag, Wien.

[10] Chsaka, H. (1965) Auto-ecology of Alopecurus aequalis. Weed Research, 4, 20-27.

[11] Sumiyoshi, T. and Nakano, E. (2008) Winter-flooding in Ariake costal area, weeds problem of non-till mulching 
system. Journal of Weed Science and Technology, 53, 35.

[12] Nakagama, A., Miyawaki, K., Nagano, Y. and Shimoshikiryo, K. (1990) Changes of weeds-vegetation due to the differences in the paddy-field utilization-form-Soil water adaptability and viable seeds-distribution of the weeds emerging during the winter cropping-period. Bulletin of the Experimental Farm Faculty of Agriculture, Kagoshima University, 15, 25-36.

[13] Arai, M. and Miyahara, M. (1962) Physiological and ecological studies on Barnyard Grass (Echinochloa crusgalli Beauv.var.oryzicola Owhi.) IV on the death of seeds in process of dormancy awaking. Japanese Journal of Crop Science, 31, 190-194. doi:10.1626/jcs.31.190

[14] Asano, H., Terasawa, T. and Hirose, S. (1981) Effect of different temperature and light intensity levels on growth in early stage of barnyardgrass. Journal of Weed Science and Technology, 26, 36-40. doi:10.3719/weed.26.228

[15] Yamagishi, J. and Takeuchi, Y. (1975) Ecological characteristic of Eleocharis kuroguwai-Development ecol- ogy. Journal of Weed Science and Technology, 14, 54-56.

[16] Sawai, K., Nishi, S. and Adachi, A. (1975) Ecological characteristic of Sagittaria triforia-Second report generation from seed. Journal of Weed Science and Technology, 14, 76-78.

[17] Ito, K. (1989) Ecology and control methods studies of Sagittaria trifolia L. in paddy field. Journal of Weed Science and Technology, 34, 13-14. doi:10.3719/weed.34.Suppl_13

[18] Ito, K. (1988) Spread of herbicide and Holocene of arable weeds. In: Yano, S., Ed., The Vegetation of JapanEcology of the Invasion and the Disturbance, Tokai University, Tokyo, Japan, 145-158.

[19] Mineta, T., Koizumi, N. and Ishida, K. (2009) Contribution of winter-flooding in multi-functionality of paddy fields-Some notes in a case of biota conservation function in Tajiri-Shinpo Miyagi prefecture. Transactions of Rural Planning, 6, 335-340. doi:10.2750/arp.27.335 